\section{The Oldest known Rocks of the Earth's Grust.}

May I welcome Prof. A. P. Coleman's letter on "Geology and the Nebular Theory" in NATURE for June I7, p. 775 ? It must be admitted that the achievement of A. C. Lawson at Rainy Lake in I887, the elucidation by Sederholm of the floor of Finland, and the illuminating work of Canadian geologists, including Coleman, Adams, and Barlow, on the Grenville Series, have been slow in penetrating academic circles in the British Isles. The doorways were almost closed against them, and against the views of French geologists also, by the dead-weight of theories of dynamic metamorphism. Yet our confidence in a fundamental "Lewisian" gneiss was well shaken thirty years ago by Sir A. Geikie's announcement that this rock penetrated a sedimentary series (see A. Geikie, " Text-book of Geology," $4^{\text {th }}$ ed., vol. 2, p. 89o); and a more detailed acquaintance with the ground would have led the same observer to withdraw his statement (ibid., p. 895) as to a "violent unconformability" between gneisses and Dabradian sediments in north-west Ireland. Some of us have lost no opportunity of comparing the conditions in our homeland with those of broader Archæan areas. But even in our narrow lands, as I have ventured to urge from Igoo onwards, the teaching of the rocks themselves is unmistakable. The oldest known rocks are sediments, and the streaky structure of our ancient gneisses again and again records the stratification of ordinary sediments invaded by a granite magma.

I have recently put this view before those who may not be geologists in a volume of " unconventional essays," containing a chapter on " The search for the foundation-stones," where Prof. Coleman will find that his expositions have not been thrown away upon those whom he has so kindly guided in the field.

Grenville A. J. Cole.

\section{An Exception to the Principle of Selection in Spectra.}

In a recent communication (Phil. Mag., April I922) Messrs. Foote, Mohler, and Meggers have described the excitation of a certain type of combination lines in a new form of discharge tube in which the applied electrostatic field can exert no influence upon the radiation. Thereby they made it somewhat doubtful whether these and other exceptions to the principle of selection can be attributed to the incipient Stark effect of the applied field, as suggested by Sommerfeld and others. In reply to this, Prof. N. Bohr has pointed out (Phil. Mag., June, I922) that, "owing to the screening from external forces, the experimental arrangement described would be especially favourable for the accumulation of ions in the region of the discharge tube," and that "the field due to the neighbouring ions and free electrons, to which the emitting atoms have been subject, may be of the order of magnitude claimed by the quantum theory for the appearance of the new lines.' Consequently Prof. Bohr thinks that the results of Foote, Mohler, and Meggers do not furnish a sufficient basis for the conclusion they have drawn.

Recently, however, in the course of an investigation on the absorption spectrum of potassium, the results of which will be published shortly, the combination lines $1 s-2 d\left(\lambda_{4} 6_{42}\right)$ and is $-3 d\left(\lambda_{3} 649\right)$ have been obtained as absorption lines. The existence of free electrons and the consequent electrostatic field of atomic origin in the absorption tube is highly improbable. The present experiment therefore seems to support the conclusion drawn by Messrs. Foote, Mohler, and Meggers.

Spectroscopy Laboratory,

Imperial College of Science and Technology, South Kensington, S.W.7.

\section{The Melbourne University Bill.}

IN the issue of NATURE for March I6, which has just reached Australia, there is a leading article on the Melbourne University Bill. That Bill was drafted more than eighteen months ago, and though we have a Government in sympathy with the highest ideals of our University, it is still a Bill and has not yet become an Act of Parliament. In the article in question reference is made to a statement drawn up by the University Association of Teachers, in which the council of the university is criticised for failure adequately to protect the interests of the university and its staff.

It would be unseemly, and probably uninteresting to a large section of your readers, to enter into the merits of a "family quarrel" which is the result of misunderstanding and is, we hope, of a temporary character. A letter was sent by the council to the Minister for Public Instruction immediately after the council was informed that the statement to which you refer had been forwarded to members of the Cabinet by the University Association of Teachers. Let me point out a fact of which you may not be aware, namely, that while the association contains the majority of the teaching staff it does not represent the whole body of professors and lecturers. The statement of the association is crude and contains serious inaccuracies. I shall deal only with the two criticisms of the council which you single out.

(I) It " failed to protect the interests of the university by not raising fees." That is not a mere financial question-it involves a question of general policy. In view of the fact that an important section of our community believes that the university should charge no fees (the University of Western Australia is free), would it not be childish to raise the fees before Parliament has settled what our grant is to be, and till we know definitely whether that grant will enable us to pay adequate salaries without raising them ?

(2) The council failed " by asking for an inadequate increase of the State Grant." I wish we could have an increase of the grant for the asking. I think the attitude of the council is clearly indicated by an extract from the letter to the Minister for Public Instruction already referred to. You will there find the following :

"The council is placed in a false position by being obliged to correct these statements, for it does not wish it to be inferred that it thinks the proposed increase of the University Grant sufficient for what are now in I92 I its legitimate needs."

The management of the university council may not satisfy the impatience of some, but no one interested in university education need fear that it will fail for lack of whole-hearted zeal.

J. H. MacFarland, Chancellor.

The University of Melbourne, May 5

[The two criticisms to which Sir J. H. MacFarland, chancellor of the University of Melbourne, refers, were made by the University Association of Teachers, and we expressed no opinion upon them, but we remarked, "It is obvious that if a university staff is thoroughly discontented its efficiency is bound to suffer." The suggestions made at the end of our

$$
\text { NO. } 2749 \text {, vOL. I IO] }
$$

